\title{
Reviewing Flexibility in Housing with Free Sorting Method
}

\author{
Konutta Esnekliğin Serbest Sınıflama Yöntemi ile Değerlendirilmesi
}

\author{
Melisa DiKER, ${ }^{1}$ (D) M. Tolga AKBULUT²
}

\section{ABSTRACT}

It is seen that houses which fail to satisfy user needs -even though they are newly built- are modified/transformed by users. As these modifications and transformations sometimes require significant physical procedures in inflexibly-designed houses, it causes some loss in terms of money, work-force and time. It can be stated that houses with "Flexible Design" characteristics are more suitable as they can answer to these modifications and transformations more easily. For that reason, the main purpose of the study carried out within this article can be summarized as to contribute to sustainable house manufacture methods by revealing users' perception of flexible house concept and how they define flexibility in house, supplying data for design processes in new house manufacturing process. The article is comprised of subtitles in which; flexible house concept in Turkey and the world is presented based on the literature, information is given about types of flexibility in house and spatial and functional flexibility parameters, method of the study is explained, obtained data is evaluated and presented results are discussed. In this study carried out with the aim of understanding users' perspectives on flexibility, multiple sorting method, which was exercised by examiners like Hershberger, Sanoff, Groat in their works, was utilized and 20 photo cards, determined with the choice of experts on their subjects (architectures-interior designers) according to spatial and functional parameters in house were used in order for participants to classify and define them. The study was carried out with the contribution of 70 participants, designated according to the differences on their gender and education levels, participants noted the data they sorted and defined, and content analysis was performed for this data. Ultimately, it was found out that participants sorted and defined these photographs under 13 categories and obtained data was assessed and discussed within the study.

Keywords: Flexible housing; free sorting; multiple sorting method; types of flexibility.

ÖZ

Kullanıcı ihtiyaçlarına cevap veremeyen konutların -yeni üretilmiş olsalar bile- kullanıcılar tarafından değiştirilip, dönüştürüldükleri görülmektedir. Esnek tasarlanmayan konutlarda bu değişim ve dönüşüm kimi zaman önemli fiziksel işlemler gerektirdiğinden beraberinde ekonomi, zaman, iş gücü gibi kayıplara neden olmaktadır. "Esnek Tasarım” özelliğine sahip konutların bu değişim ve dönüşüme daha kolay cevap verecekleri ve kullanıcı ihtiyaçlarına daha uygun olduğu söylenebilir. Bu nedenle makale kapsamında yürütülen çalışmanın temel amacı, kullanıcıların esnek konut kavramından ne anladıklarını ve konutta esnekliği nasıl tanımladıklarını ortaya koyarak, yeni konut üretiminde tasarım süreçlerine veri sağlayarak, sürdürülebilir konut üretimine katkıda bulunmak olarak özetlenebilir. Makale, dünyada ve Türkiye'de esnek konut kavramının literatüre bağlı olarak ortaya konduğu, konutta esneklik türleri, mekânsal ve işlevsel esneklik parametreleri hakkında bilginin verildiği, çalışma yönteminin açıklandığı, elde edilen verilerin değerlendirildiği ve ortaya konulan sonuçların tartışıldığı alt başlıklardan oluşmaktadır. Kullanıcıların esneklik hakkındaki bakış açılarını öğrenmek amacıyla yürütülen bu çalışmada, Hershberger, Sanoff, Groat gibi araştırmacıların da çalışmalarında kullandıkları çoklu sınıflama yönteminden yararlanılmıştır. Katılımcıların sınıflandırmaları ve tanımlamaları için konusunda uzman (mimar-iç mimar) kişilerin seçimiyle konutta mekânsal ve işlevsel parametrelere bağlı olarak belirlenen 20 adet fotoğraf kartı kullanılmıştır. Çalışma, cinsiyet ve eğitim durumu farklılıklarına göre seçilen 70 katılımcının katkısı ile gerçekleştirilmiştir. Katılımcılar sınıfladıkları ve tanımladıkları verileri not etmişler ve elde edilen verilere içerik analizi uygulanmıştır. Sonuçta katılımcıların gösterilen fotoğrafları 13 kategori altında sınıflandırdıkları ve tanımladıkları belirlenmiş ve elde edilen veriler değerlendirilerek çalışma kapsamında tartışılmıştır.

Anahtar sözcükler: Esnek konut; serbest sınıflama; çoklu sınıflama yöntemi; esneklik türleri.

This article was produced from the thesis study titled "Evaluation of the Concept of Flexibility in Housing in the Context of User Preferences" prepared by Melisa Diker under the supervision of Associate Professor M.Tolga AKBULUT at YIldız Technical University Institute of Sciences Architectural Design Doctorate Program.

'Department of Architecture, İskenderun Technical University Faculty of Architecture, Hatay, Turkey

${ }^{2}$ Department of Architecture, Yıldız Technical University Faculty of Architecture, İstanbul, Turkey

Article arrival date: June 18, 2020 - Accepted for publication: February 22, 2021

Correspondence: Melisa DiKER. e-mail:melisa.diker@iste.edu.tr

○ 2021 Yıldız Teknik Üniversitesi Mimarlık Fakültesi - @ 2021 Yıldız Technical University, Faculty of Architecture 


\section{Introduction}

Population residing in Turkey, compared to the previous year as the date 2019, increased by 1 million 151 thousand 115 people, has reached 83 million 154 thousand 997 people (TUIK, Address Based Population Registration System, 2020). With the rise of the population in our country, a rise in demand for housing is seen, too. Designing these houses flexible according to the needs and demands of population is thought to be important in social, cultural, economic etc. aspects.

Housing sales across Turkey in August 2020 has increased by $\% 54.2$ compared to the same month of the previous year and was 170 thousand 408 (TUIK, Housing Sales Statistics, 2020). In addition, in the Building Permit Statistics, the highest share according to the purpose of use was the houses with two or more flats with 73.2\% (TUIK, Building Permit Statistics, 2020). Houses, which are the most produced building types in the country, are transformed according to the needs of the user over time or abandoned due to their inability to meet the needs. Flexible houses' designs, convenient for modification and transformation, are thought to be able to create a significant advantage in terms of preferability in housing industry and within this study it is tried to present the concepts that users perceive as "flexibility in house". In this context, concept of flexibility in house is put forward based on the literature, information is given about spatial and functional flexibility, and photographs determined by specialists according to this consideration are assessed with free sorting method by 70 participants, designated considering their differences on gender and education levels. The results obtained in the study are discussed and evaluated and it is tried to understand users' perception on flexibility in house.

\section{The Concept of Flexible Housing in the World and} Turkey

Hertzberger, (1991) who expresses that flexibility provides a solution for architectural problems, states that neutrally designed buildings, as they might have different utilizations, at least in theory, assimilate the effects of ever-changing time and condition and adapt to them (Hertzberger, 1991, p. 146). Priemus (1993) defines flexibility as a general necessity to make reorganization on changes that might occur; Karni (1995), on the other hand, defines it as the ability to adapt to new conditions. So, alterations, transformations and arrangements practiced in the space and different types of use become a result of the natural structure of flexibility. Schneider and Till (2007, p. 5) who state that the word of flexibility constitute an almost instant potential for movement and change, remark that flexibility has a simple relation with progress, with the idea of a moving thing will escape from the barrier of tradition and something that is changed will be new forever. In a similar way, Kızmaz and Çimşit Koş define the reason to perform flexible approaches in architectural design as controlling possible scenarios and the desire to have solutions for the problems even before they occur in the design (Kızmaz and Çimşit Koş, 2015, p. 116) and support the visionary approach of flexibility. The most general definition of flexible design characteristics in terms of housing can be put as the house that carries flexibility characteristics within its structure and is able to adapt to changing conditions, needs, demands and time. According to Schneider and Till $(2007$, p. 4), flexible house is the one that can adapt to ever-changing needs and forms (models) both socially and economically. These changing needs might be personal (expanding family), practical (aging) or technological (renovating old services). And forms (models) that change might be demographic (individual home ownership), economic (occurrence of tenants) and environmental (houses responding to climatic changes) (Schneider and Till, 2007, p. 4).

Flexibility, a long-established and extant design feature, originally occurred in the form of versatile use with practices of different functions as eating-resting-sleeping in the same place in traditional houses. Küçükerman and Güner, who state that features like forehandedness and versatility have a significant role in the formation of spatial identity in Turkish house, mention a single place meeting all the daily functional needs on its own (Küçükerman and Güner, 1994, p. 43). Also, Bektaş, stating that flexibility is one of the most important elements in Turkish house, remarks that a house can expand unit by unit or can be divided later on depending on the family's expansion (Bektaş, 1996, p. 32). Both Küçükerman and Güner also Bektaş emphasize that Traditional Turkish Houses have flexible characteristics.

Apart from the Turkish House, especially Japanese houses possess flexible features, too. The rooms in Japanese houses, according to Yagi (1982) enable the space to be changed optionally by means of mobile dividing walls and furniture (Torun, 2018, p. 103-106).

Traditional house manufacturing has left its place to industrial house manufacturing with the development of production systems and construction technologies. In the 18 th and 19th centuries, house manufacturing process has become faster, easier and more economic than previous times. Load-bearing walls, leaving their duty to structural elements (column-girder etc.), enabled non-load bearing walls to gain the ability to move. In addition to that, the development of construction technology has enabled the practice of long span spaces and open space formation.

According to Priemus (1993), The Domino house, designed by Le Corbusier in 1914, is a good example that 

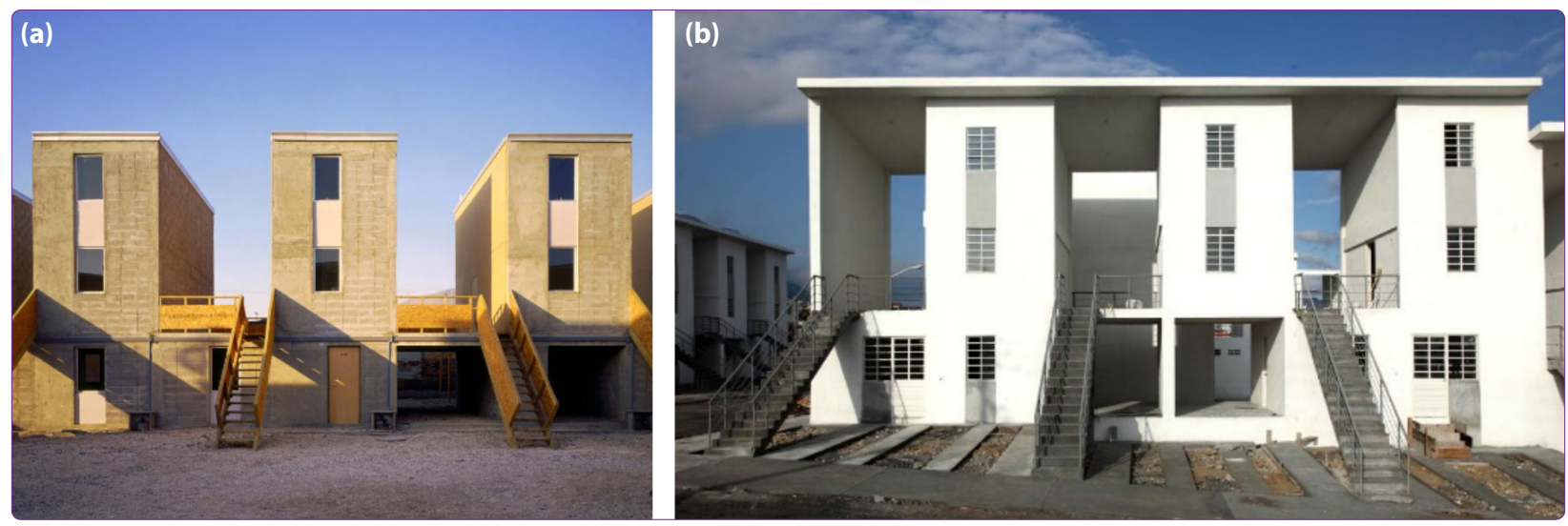

Figure 1. Flexible and incremental house examples designed by Aravena: Quinta Montroy Houses ${ }^{1}$ (a) and Monterrey Houses ${ }^{2}$ (b).

reflects the concept of flexibility as it enables creating numerous floor plans with reinforced concrete columns, flooring and completing elements (Priemus, 1993, p. 19). According to Schneider and Till (2007), Schröder House, designed by Gerrit Rietveld in 1925, on the other hand, is among the buildings that own mobile parts and is counted as an influential structure in flexibility history in architecture (Schneider and Till, 2007, p. 5). In the Schröder House, space can be divided for different functions thanks to the sliding doors and open plan layout and thus flexibility is achieved.

Between 1920-1950, generally open plan layout was provided by creating big spaces in houses. Besides, thanks to the modular layout and design made in the houses during these years, it became possible for spaces to move by means of mobile walls or dividing walls. The notion of flexible design for spaces came up with transformable furnishing elements like rollaway bed, sliding doors and prefabricated furniture (especially for bathroom and kitchen etc.). In 1950-60's the concept of core housing occurred. According to Gülaydın, core housing is a nonfinished house type, starting from minimum size, capable of expanding and ready to be completed by a consumer or an institution (Gülaydın, 2004, p. 38). In 1960's, with the development of building systems, support system and infill system separated; interference of the user in filling systems and the importance of user's participation in house design have been brought to agenda. According to Habraken, who states that a building is composed of infill and support levels (Habraken, 2002, p. 12), supporting structure is a formation that enables houses to be built, transformed and disassembled independently from other structures (Habraken, 1972, p. 59-60). Infill elements, on the other hand, exist in built environments such as walls, kitchen-bathroom equipment, in a lower level in comparison to the building (Habraken, 2002, p. 12). With modifiable infill equipment, a flexible utilization occurred in housing units. Also, in this period of time, flexible housing designs are provided with modular design, mobile walls, locating wet areas together, interstage recovery with staircase and similar criteria. Reaching to the 1990's, by solving the complications of applying a plumbing system in raised flooring, the concept of moving wet areas gained attention. After 2000, a different flexible housing approach developed with distinguishing units called incremental housing, that is half-completed, half reserved to be completed later on, depending on the user's financial conditions and needs. Quinta Monroy houses, designed by Aravena in 2003, can be the best example of it (Figure 1a). According to Aras, users in these houses own flexible houses in which they can make the changes they want anytime without experiencing a budget crunch (Aras, 2016, p. 184). Designed in 2010 in Chile by Aravena, who won the Pritzker award in 2016, Monterrey Houses, which present an example of incremental housing (that can be completed subsequently), are a good representative to demonstrate that flexibility in the matter of housing is of great importance in recent years, too (Figure 1b). The flexible designs that Aravena presented for low-incomers and poor, can also be described as a social approach that can enable poor urban people inhabit without dislocation and allow house development within their low income in time. During this time, apart from incremental housing, with the method of adding or removing modules from the structural construction, flexible approaches occurred which made it possible to add/remove intended spaces according to needs in houses.

In addition to these flexible design approaches that were developed in this period, different spaces were created by moving or rotating some units and flexibility was obtained by using the space for different purposes. Furnishing

https://www.archdaily.com/10775/quinta-monroy-elemental/50102df128ba0d4222000ff7-quinta-monroy-elemental-image?next_project=no (Data of Access: 28.04.2020).

https://www.archdaily.com/52202/monterrey-housing-elemental/50089c3028ba0d50da001309-monterrey-housing-elemental-photo?next_project=no (Data of Access: 7.11.2020). 
elements like sliding door, mobile furniture, rollaway bed, multi-purpose cabinet have been used to divide, expand or transform the space in the 2000's as they had been used before, contributing to the development of flexible space.

As for the flexible houses built in Turkey, open plan houses with modular design and their capability to enlarge or scale down stand out. Interstage recovery with the staircase element located on the ground floor in loft houses enables houses to enlarge vertically. Apart from this, shared space units like terrace, yard or garden bring flexibility to house and settling, as they are used for different purposes. In houses with different types of plans, having apartments with different scales considering user needs present a flexibility for their choices, too. Aside from this, in Turkey, other flexible housing examples are also encountered which are created with solutions like users' participation in house design process, locating plumbing system and cores together, open plan layout and transformable furniture (rollaway bed, multi-purpose cabinet etc.).

\section{Types of Flexibility in House}

It is seen that types of flexibility are gathered under different titles by different researchers. Flexibility, according to some researchers, is divided into three groups as spatial-functional-cultural. Van Eldonk and Fassbinder (1990) mention the expression of "character flexibility" which refers to possible changes in architectural quality, facade and identity of the house, except from functional (without professional interference) and spatial flexibility (with professional interference) (Lans and Hofland, 2005). According to Al-Dakheel (2007), flexibility has three components which are functional flexibility: the transformation of space and its ability to transform the space, structural flexibility: the ability to lengthen the space horizontally-vertically and using modularization system, cultural flexibility: the ability to personalize the space (Al-Dakheel, 2007).

Gilani (2012) expresses Dittert's and Van EldonkFassbinder's flexibility classifications as: spatial (structural), functional and characteristic flexibility. Spatial flexibility is the ability to change the conditions depending on professional interference. This flexibility is not only related to structural changes, but also to physical alterations that happen in the interior. Functional flexibility is the ability to change the conditions without professional interference. Residents are able to meet their needs and wishes indoors without any structural changes. It is based on assigning functions to spare/excess rooms and changing room functions and the relation between the rooms. Characteristic flexibility enables changing façade and house identity. It mentions the appearance of architectural quality (Gilani, 2012, p. 19-20).
Aside from spatial, functional and character flexibility classifications, Yürekli (1983) divides flexibility into two parts as design and usage flexibility. While design flexibility enables practicing arrangements considering different needs on the project before construction and usage processes, usage flexibility is defined as leaving the changes in the structure to be handled after the building's completion, in the usage period (Yürekli, 1983, p. 11-12). Deniz (1999) on the other hand, examined flexibility under the topics of design, usage and construction flexibility (Deniz, 1999, p. 12).

Based on the descriptions made above, although types of flexibility are acknowledged under three main titles as structural, functional and cultural flexibility, cultural flexibility is excluded from this study; while types of structural and functional flexibility are discussed within this work. Besides this study is limited to design flexibility that is regulating the structure according to flexible characteristics in the design process.

\section{Spatial and Functional Flexibility Parameters in House}

Spatial flexibility in house can be expressed as the ability of space to be modified physically thanks to its design characteristics. Functional flexibility can be described as an interior alteration capability without making a change on physical characteristics and area of the space and the capacity of different spaces' formation. Within this work, spatial and functional flexibility parameters that are obtained and interpreted based on the literature are reviewed and spatial flexibility is examined in eight subcategories and functional flexibility in five sub-categories. In Figure 2, descriptions of spatial and functional flexibility parameters and their graphical reflections are given as a further explanation.

The descriptions of 12 parameters, that are reviewed based on spatial and functional flexible design characteristics in house, are as follows:

Spatial Flexibility Parameters:

- Enlarging-Downsizing Space: Enlarging and downsizing space by adding/removing room from the space.

- Modular Space: Manufacturing space in certain sizes that can enable modification.

- Mobile Space: Spaces that move physically/modify in the space.

- Industrial Boxes: Prefabricated spaces that can be added or removed structurally from the space.

- Loft Space: Spaces that are designed as open plan spaces and own interstage usage.

- Mobile Wall: Non-load bearing wall that can move to create different spaces. 


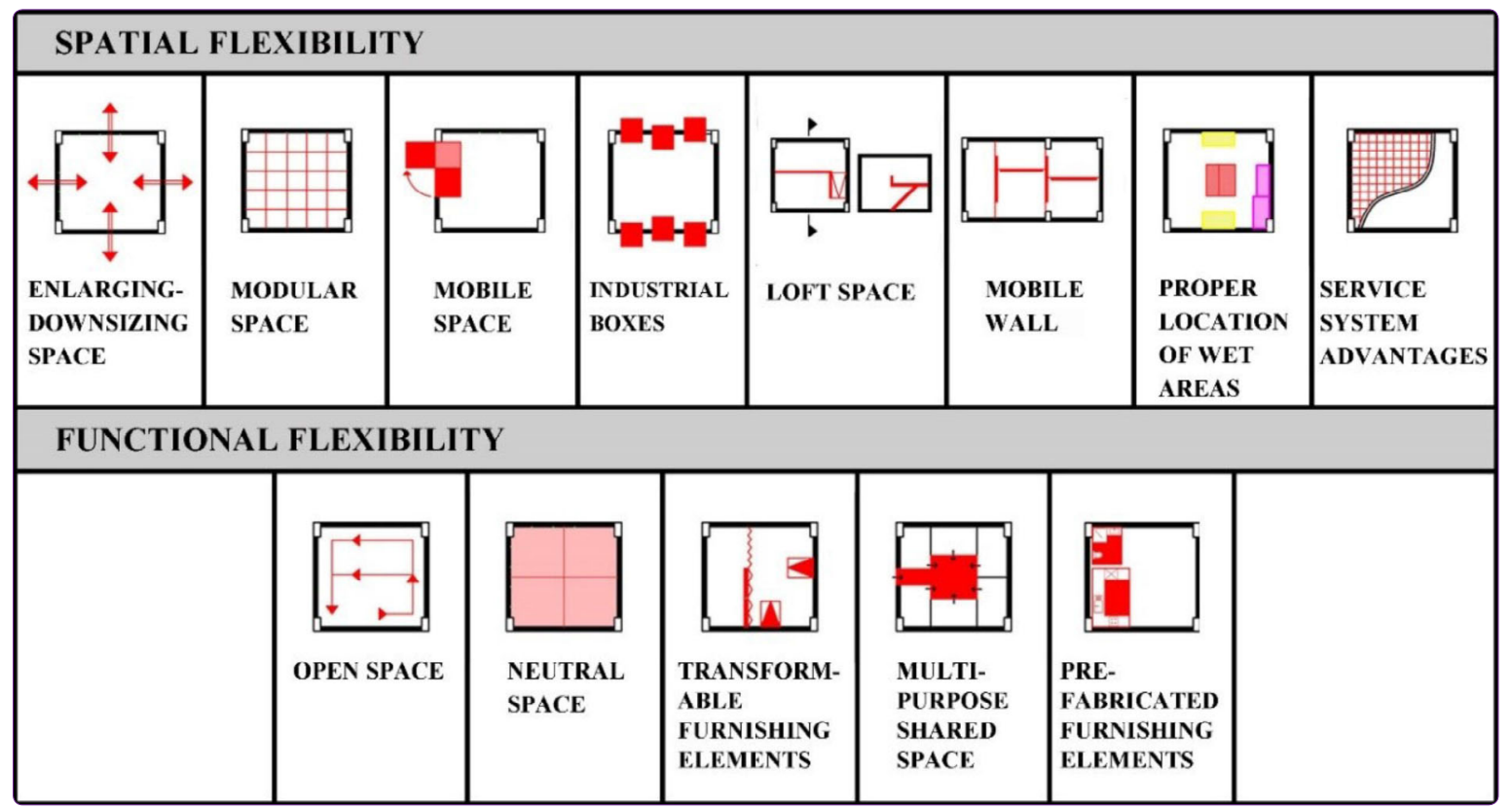

Figure 2. Spatial and functional flexibility parameters.

- Proper Location of Wet Areas: Locating wet area solutions (water closet-kitchen-bathroom etc.) in a suitable place for flexible design.

- Service System Advantages: Raised ceiling, raised flooring or mobile plumbing systems that can enable flexible design solutions.

Functional Flexibility Parameters:

- Open Space: Unobstructed free spaces which enable different functions.

- Neutral Space: A space capable of different functions as it is not privatized.

- Transformable Furnishing Elements: Furnishing elements like rollaway bed, mobile/reversible cabinet or foldaway furniture that enable different space formations.

- Multi-Purpose Shared Space: Areas that make it possible to perform multiple functions together in the space.

- Prefabricated Furnishing Elements: Furnishing elements that are readymade and mobile.

\section{Method Used Within the Work}

Within this work, users' perspective of house flexibility is examined by free sorting method, which is a part of multiple sorting method. In this sorting method, according to Groat and Wang, the participant is asked to sort a series of cards (generally 20-30 pieces) with a word or a picture on it. In a directed sort, the examiner determines a series of categories that cards should be sorted in like 5-7 points rating scale from the most preferred to the least preferred ones, while in an open sorting the participant determines categories that she/he finds meaningful (Groat and Wang, 2013, p. 294). According to Sanoff, multiple sorting method lets people sort the elements freely according to their own criteria within categories they define. This method not only sorts the elements, but also reveals individual category diagrams and related sense and associations (Sanoff, 1991, p. 5).

The reason to choose free sorting method in this work is that the objects (e.g. a photograph card) sorted by the participants freely (without directions) have a correspondence in terms of meaning when they are tagged. By this means, it is thought to be possible to understand users' perspective about house flexibility conceptually.

The sorting method practiced in the study, according to Groat and Wang, is described as data collecting method in correlational research strategy. Correlational research strategy is divided into two main types as relationship and causal comparison (Groat and Wang, 2013, p. 294, p. 272). It can be stated that this study is more suitable for causal comparison within correlational research strategies.

In causal comparative studies that exist in a midsection at the center of causality which characterizes experimental works and visionary approaches of relation studies, the researcher collects data about related variables by choosing comparable people groups or physical settings (Groat and Wang, 2013, p. 275). This study also shares similar aspects with quasi-experimental research. According to Wang and Groat, quasi-experimental research is generally used in field occasions in situations where people or physical variable cannot be assigned randomly due to ethical or practical reasons. In such circumstances, researcher 
tries to determine or establish an effective comparability between as many variables as possible (Groat and Wang, 2013, p. 322). This study is a quasi-experimental research and a part of causal comparative correlational research, as participants are chosen according to their gender and education level differences and photo cards about spatialfunctional flexibility are assessed.

Some researchers, who use multiple sorting method in their studies, (Hershberger; 1973, Sanoff; 1973, Groat; 1982, Scott and Canter; 1997, Erdoğan; 2010) analyzed the conceptual perception differences among the participants with classification of photographs. In Hershberger's study, where he states that there is an environmental difference between architect students and non-architect students (Devlin, 1990, p. 236), colored photograph slides of 25 buildings have been demonstrated to a total number of 47 students (Hershberger, 1988, p. 176). In the study, factor analysis was sourced, and three common factors were obtained from each group's answers (Hershberger, 1988, p. 179). In Sanoff's study, where he aims to discover youth's perception of environment's social meaning, 150 high school students, living in both urban and rural areas, were asked to define similarities and differences among 12 distinctive photographs of settlements. More than 60 definitions were made for 12 photographs, and these were sorted under seven categories after going through a content analysis (Sanoff, 1973, p. 84-87). In Groat's work, which he practiced with the aim of testing interpretation differences concerning Post Modern and Moderns buildings, he reviews 24 house photographs with an array of style from PostModern to Modern, with the participation of 20 architects and 20 accountants using multiple sorting method. To analyze the data gathered, multi-dimensional scaling analysis, scalogram analysis and content analysis were used (Groat, 1982). Scott and Canter, assess a theoretical and empirical difference by using multiple sorting method, while reviewing pictures and the places they represent. So, 41 participants sorted 20 photographs of local places they are familiar to, both freely and directedly (thinking for several minutes about the places they see in the pictures) (Scott and Canter, 1997, p. 263). In Erdoğan's study, where he aims to discover similarities and differences in assessing the structures (Erdoğan, 2010, p. 10-11), 83 undergraduate architecture students ( 43 freshmen and 40 senior students) made an interpretation of 21 structures with different functions. After the interview which constituted the contents of content analysis, the form of multi-dimensional scale and Indscal method, 415 groupings were made and these groups were gathered under 11 categories (Erdoğan, 2010, p. 74-78).

In the works of Hershberger, Sanoff, Groat, Scott and Canter and Erdoğan, approximately 20 photographs were picked in accordance with the subject of the study and multiple sorting method was applied in a free and/or directed way. In general, the data gathered was subjected to content analysis. Within this work, similar to the studies made, 20 photo cards, whose relation to flexibility was determined by experts, were picked and these photo cards were given to participants to be sorted freely. The tags generated were reviewed via content analysis and users' perception of flexible house was assessed.

\section{Choosing Suitable Photographs According to Spatial and Functional Parameters and Performing the Method}

Before choosing the photographs to be used in the study, it was designated which category of spatial and functional flexibility parameters to choose, and a research was made about picking out pictures that would reflect these categories in the best way. The selected categories were "loft space" and "mobile wall" parameters from spatial flexible house parameters as stated in the Figure 2 and "open space" and "transformable furnishing elements" categories from functional flexible house parameters. Together with these categories, "inflexible space" category was added. The reason to choose these categories is that they are the most distinct and common parameters related to design that define flexibility in house and enable perceiving and reading flexible design characteristics concerning the use of space horizontally and vertically via photographs easily. Structural flexibility characteristics, which are more difficult to figure out through photographs and require a more extensive approach in terms of practice, are excluded from the study.

After performing online photograph browsing about these five categories selected in the study, 40 photographs (eight photographs for each category) were chosen and these were reduced to 20 photographs (4 photographs for each category) by an expert group (11 academician, architect and interior designers). These selected 20 photographs were the ones that the expert group, informed about 5 categories, designated by giving the highest points and thought to be the best ones to reflect the characteristics of their category (Table 1).

These photographs were organized as color printout on A5 sized white cardboards, each carrying a number on the back. While performing the method, at first, participants were informed about the purpose of the work and then asked to sort 20 photo cards freely, creating categories meaningful for them in any number they want. At this point participants could include as many photographs as they want in each group they categorize. Afterwards, participants were asked to explain the reason they included these photographs in the groups or to name/tag 
Table 1. Flexibility categories in the study, definitions explained to the expert group and photographs used (photo references are at the end of the article)

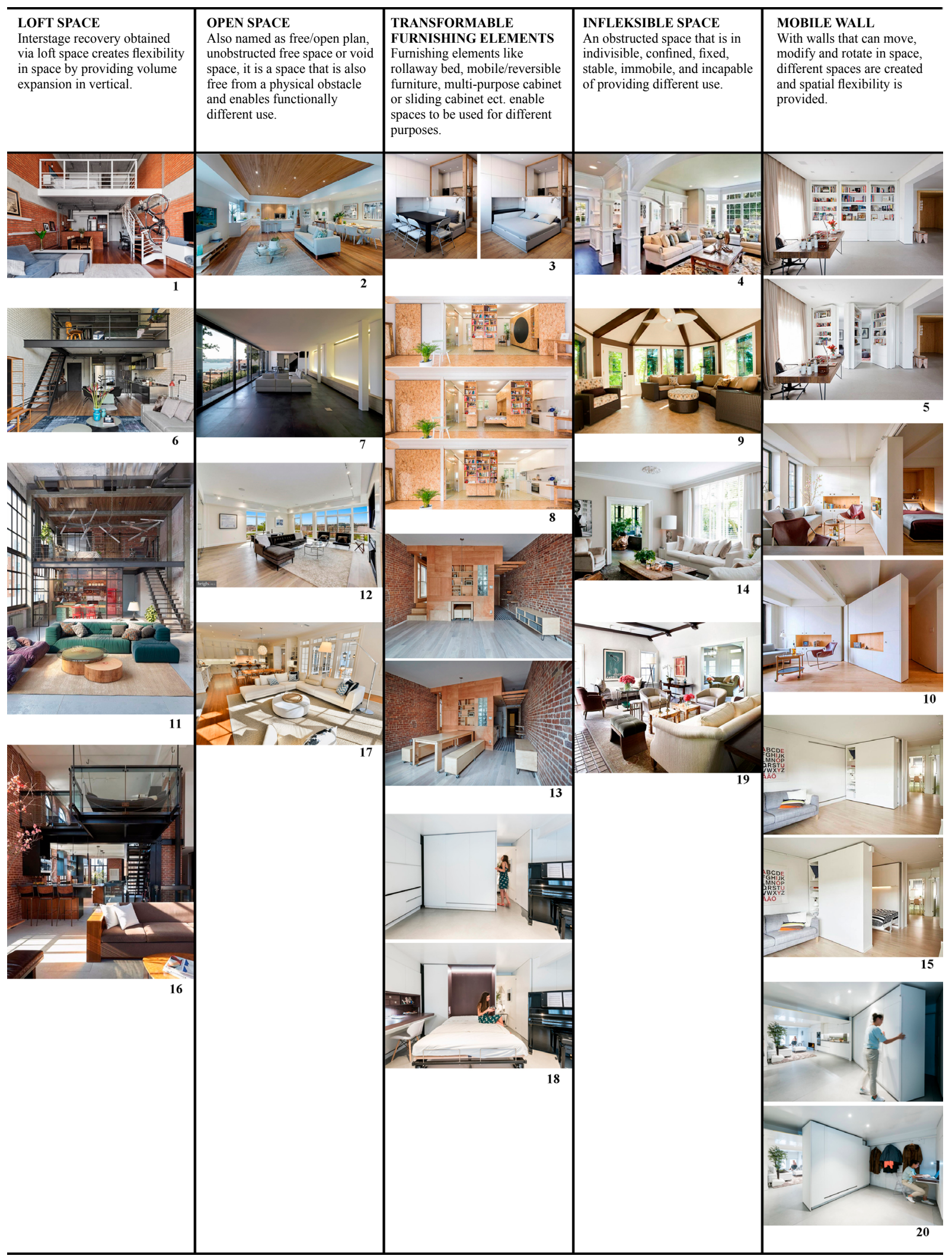

each group. In the meantime, all the group names given by participants were noted in the questionnaire. Performing this method lasts approximately 15-20 minutes, although it varies according to participants (Figure 3 ). 


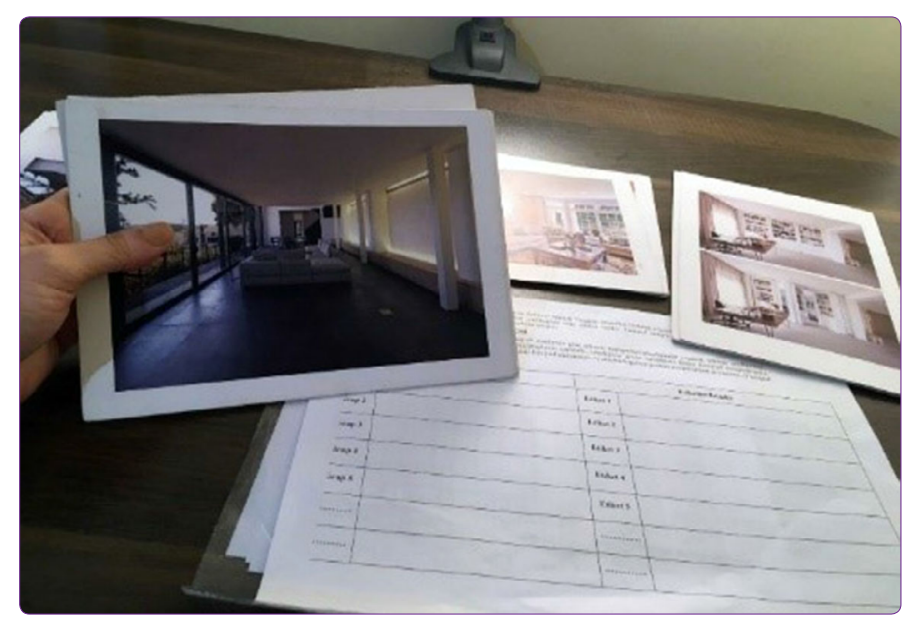

Figure 3. Performing free sorting method (2019).

Content analysis was performed for the data gathered (names given to the groupings) with free sorting method within the work. According to Wilson, content analysis is essential to systematize the verbal information that participants give in defining similarities and differences among the elements listed with free sorting method. As for Mostyn (1985), the main purpose of content analysis is to define the specific characteristics of communication systematically and objectively to transform raw material into scientific data (Wilson, 1989, p. 118).

\section{Reviewing Free Sorting Method}

Within this study, in which users' conceptual perspective on flexible house is examined using free sorting method, participants are designated based on the differences between their "gender" in terms of demographic characteristics and their "educational status" in terms of socio-economical characteristics.

In the sense of gender difference, there are studies (Kristensen, 1997; Asiyanbola, 2006) in the literature that state the differences between male and female experience, use and perception of house (Ergöz Karahan and Özüekren, 2010, p. 5). While women comment on the design and spatial organization of space and portray their ideal house, men mention the need for a balcony or barbecue in the house. This stands for an indication about men being extraverts and living outdoors, while women being introverts, living indoors and their attention channeling towards inside the house (Ergöz Karahan and Özüekren, 2010, p. 8). As there are differences in terms of gender on house perception, there is also a contrast in terms of educational status. According to Boumeester (2011), level of access to education is one of the socio-economic factors that affect house preferences (Boumeester, 2011, p. 31). Meier (2013) expresses that as a result of high levels of cultural capital and educational qualifications in household, people value the symbolic and representational qualifications of products, rather than their instrumental qualifications (Stuart-Fox, 2015, p. 9-10). Additionally, VROM-raad (2009), states that compared to classical functions of houses and their environments, their aesthetic, experimental and identity aspects have become more prominent (Stuart-Fox, 2015, p. 10).

In this study, it is assumed that participants, according to their gender and educational status difference, might have contrasting opinions on flexible designs in house. Thus, in the research, from 70 participants, that is 35 female and 35 males, 40 of them were graduates/post-graduates, while 30 of them were primary school/high-school graduates.

Designated 70 participants classified 20 photographs demonstrated to them using free sorting method and creating meaningful categories. Generally, participants divided the photographs approximately into 4 groups and 286 definitions were made for 20 photographs by participants in total.

All names/tags that participants gave to each group were gathered under 13 categories with the content analysis made. As each group was reviewed in 1, 2, 3 or 4 categories in terms of meaning, 13 categories were used 547 times by 70 participants in total. These categories, created by grouping the adjective pairs/definitions used by participants to describe the places demonstrated through photo cards, are indicated in Table 2.

According to content analysis, from the definitions that 70 participants expressed, \%21,39 of them was made according to dimensional characteristics of space, while $\% 19,38$ was made according to the impression it stirs, $\% 12,43$ was made according to flexible usage of space, $\% 10,97$ was made according to aesthetic characteristics of space, \%10,05 was made according to efficient/inefficient area utilization in the space, and $\% 8,41$ was made according to usage characteristics of space. $\% 8,04$ of the definitions was reviewed according to style of space, $\% 5,48$ according to relating space with different groups of users, $\% 2,38$ according to view of space, $\% 0,55$ according to economic perception of space, $\% 0,37$ according to its privacy, $\% 0,37$ according to environment and $\% 0,18$ according to the form of space (Figure 4). It can be expressed that, according to definitions made, participants pay attention mostly to dimensional characteristics of space, the impression it stirs and its flexible usage characteristics while reviewing a house concerning flexibility.

While reviewing 70 participants' free sorted photographs, different opinions from male-female, graduates/postgraduates and primary school graduate/high-school graduate participants were examined. In the spatial assessments made, male and female participants comment on 13 criteria mentioned in Figure 4 in similar percentages and referred mostly to dimensional characteristics of space 
Table 2. Categories created from adjective pairs/definitions

Adjective Pairs/Definitions Used by Participants

"Big-small, wide-narrow, restricted-spacious,"

"Complicated, complex-simple-plain, interesting-ordinary, like a hotel lobby, feeling of belonging, inviting, suffocating, boring, comfortable, eye straining, tiring, neat, comfort, lacking cozy home environment, light-darkness, studio"

"Multi-purpose use, Multi-dimensional use, various/optional use, mobile dividing walls, different functions existing together, transformable space, very useful/multi-functional, everything locating in the same place, foldaway-rollaway furniture, mobile walls"

"Beautiful-ugly, pleasant-unpleasant, being appreciated-being depreciated, good looking /unsightly, material-color-texture relation" "Maximum utilization of space, well-proper-bad utilization of space, saving space, space recovery, being practical"

"Modern-classical, decoration, mode, concept, style, boutique" "Dining-kitchen-bedroom-study room, living room, rest, eating, sleep" "Ideal family house, extended family house, house for young-old, house for single people, house designed for men or women"

"Having a garden, green, environment condition, view"

"Expensive, rich"

"Bedroom's position in open space (especially in loft space), lacking privacy"

"In hot climate region, in intense urbanization texture"

"Square-rectangular-round"

\section{Categories Created According to Adjective Pairs/Definitions}

Dimensional Characteristics of Space

Impression the Space Stirs

Flexible Usage Characteristics of Space

Aesthetics of Space

Efficient/Inefficient Area Utilization in the Space

Style of Space

Usage Characteristics of Space

Relating Space with Different Groups of Users

View of Space (Looking at and From Space)

Economic Perception of Space

Space's Perception of Privacy

Environment That Space Is Situated In

Form of Space and the impression it stirs. The percentage of impression the space stirs is a little bit higher in female participants $(\% 20,08)$ compared to male participants $(\% 18,73)$. In the same way flexible usage characteristics of space is mentioned in a higher percentage by female participants $(\% 13,26)$ compared to male participants $(\% 11,66)$. On the other hand, male participants $(\% 8,48)$ reviewed the style of space in a higher percentage compared to female participants $(\% 7,58)$. Similarly, usage characteristics of space were referred to by male participants in a higher percentage compared to female participants (Figure 5).
Although there are similar percentages in the assessments made according to education level differences, all participants comment principally on dimensional characteristics of space and the impression it stirs. Primary school/high-school graduates $(\% 23,71)$ mentioned dimensional characteristics of space in a higher percentage compared to graduate/post-graduates $(\% 19,68)$. In the same way flexible usage characteristics of space were reviewed by primary school/high-school graduates further. As for the aesthetic characteristics of space, graduate/post-graduates $(\% 12,06)$ mentioned them

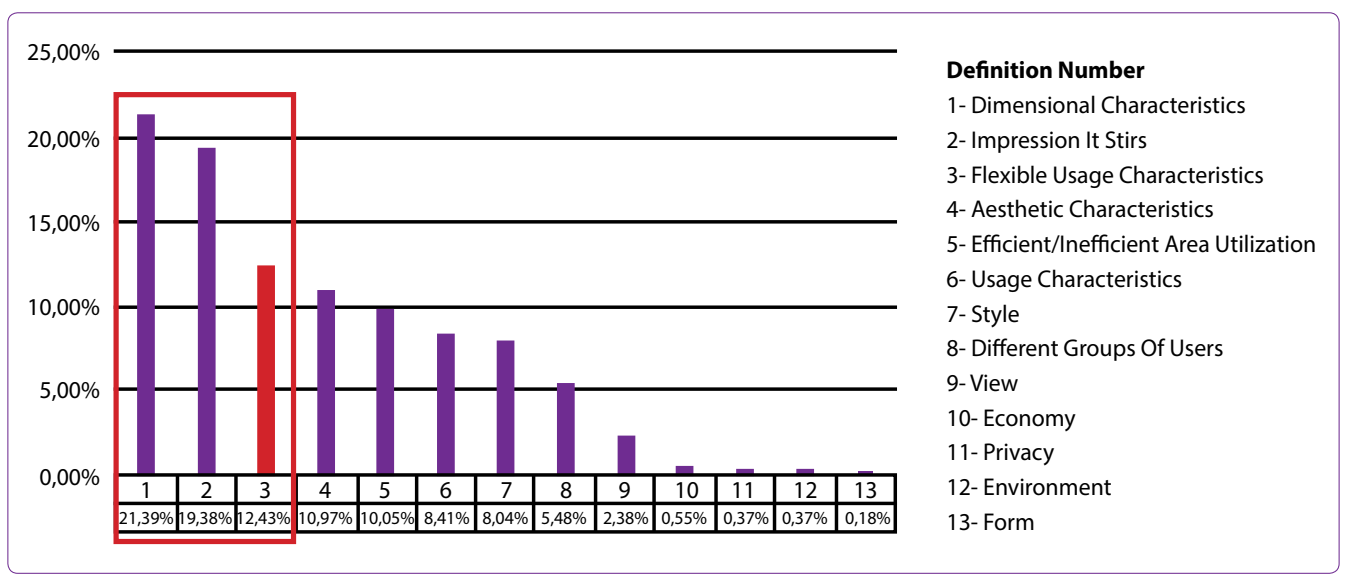

Figure 4. Photographs' review criteria by participants and their percentages. 


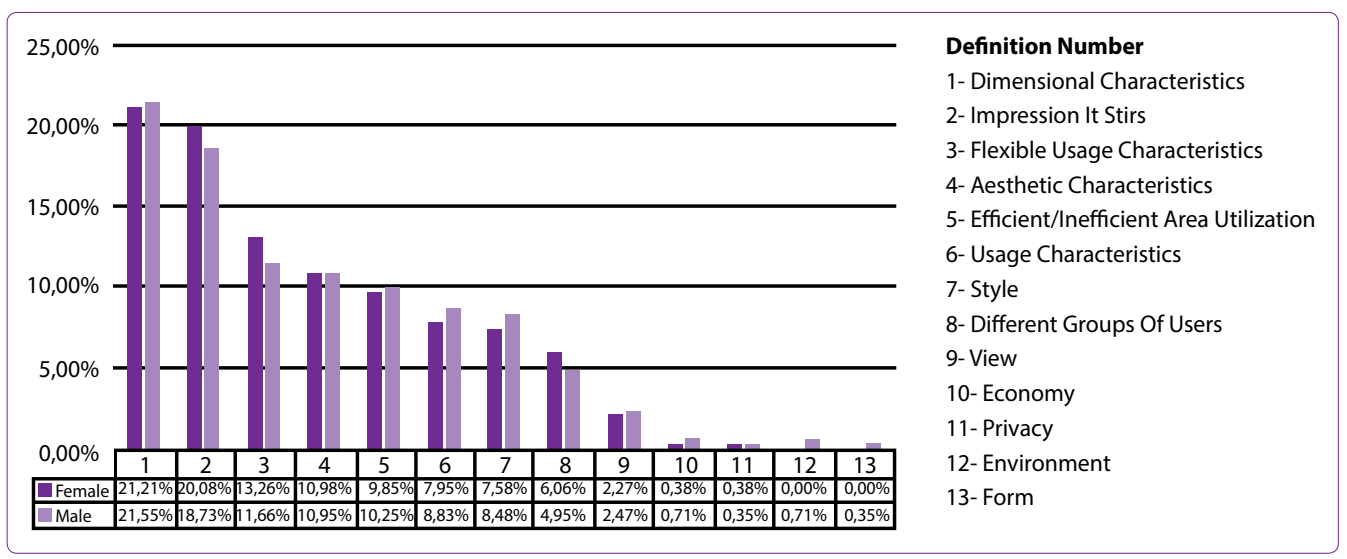

Figure 5. Photographs' review criteria according to gender differences.

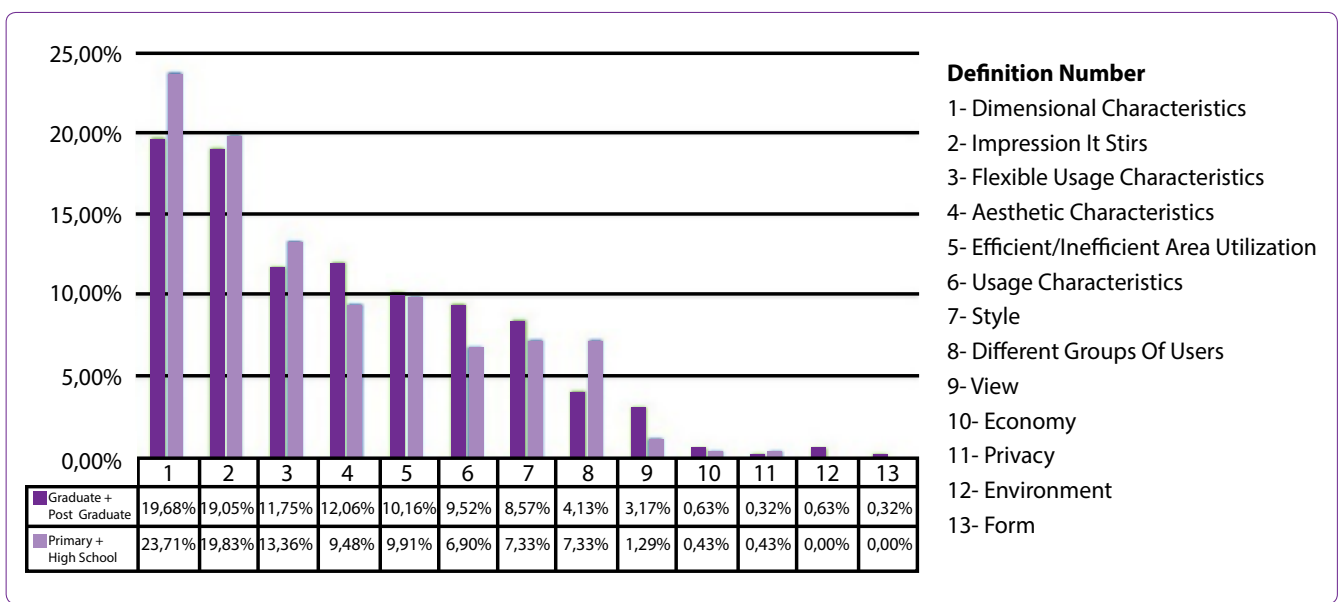

Figure 6. Photographs' review criteria according to education level differences.

in a higher percentage compared to primary school/highschool graduates $(\% 9,48)$. Likewise, usage characteristics of space were interpreted more by graduate/post-graduates $(\% 9,52)$, in comparison to primary school/high-school graduates $(\% 6,90)$. Relating space with different groups of users, similarly, was reviewed by primary school/highschool graduates $(\% 7,33)$ in a higher percentage compared to graduate/post-graduates $(\% 4,13)$ (Figure 6$)$.

To sum up, it can be stated that while all participants, reviewing house related to flexibility, mention dimensional characteristics of space, the impression it stirs and flexible usage characteristics frequently; male participants pay more attention to the style of space and female participants pay more attention to the sensual impression of space and flexible/transformable use. Moreover, it can be expressed that as participants' education levels increase, aesthetic and usage characteristics of space stand out and as participants' education levels decrease, dimensional characteristics of space and relating it with groups of users become significant.

In the review criteria of photographs, the third most important feature is flexible usage characteristics. Within this work, the category of flexible usage characteristics in house is explained by participants with the definitions below:

- Foldaway/rollaway, mobile, transformable, multifunctional furniture.

- Multi-purpose use (multi-purpose, practical).

- Different functions existing together (dining-bedroom in the same area, kitchen-living room in the same area etc.)

- Mobile wall.

While female participants $(\% 19,18)$ define flexible usage characteristics with transformable furniture, male participants' $(\% 15,07)$ descriptions are based on different functions existing together compared to female participants $(\% 12,33)$. It is seen that male participants relate mobile wall to flexibility in a lower percentage compared to female participants. If educational status difference is in question, graduate/post-graduate participants $(\% 27,63)$ define flexible usage characteristics mostly with transformable furniture compared to primary school/high-school graduate participants $(\% 6,58)$. Multi- 
purpose use as a flexible usage characteristic is mentioned by primary school/high-school graduate participants $(\% 19,74)$ in a higher percentage compared to graduate/ post-graduate participants $(\% 9,21)$. The feature of different functions existing together is reviewed in the category of flexible usage characteristics almost equally by both groups (Figure 7).

If we make an overall deduction according to the findings obtained within the study, participants,

- Made descriptions mostly as "multi-functional furniture, multi-purpose, all in one, mobile wall" that emphasize flexibility for transformable furniture and mobile wall categories. It can be stated that especially transformable furniture gets defined also with adjectives like "narrow, restricted" (category of dimensional characteristics of space and the impression it stirs) and these spaces perceived as narrow and restricted get less appreciated by participants.

- Open space photographs were generally described with adjectives like "spacious-wide-big" (dimensional characteristics category) or "pleasant-aestheticpeaceful" (categories of aesthetic characteristics of space and the impression it stirs). This situation informs us that open plan houses are found more pleasant and aesthetic and get more appreciated by participants.
- As for the loft space photographs, definitions like "duplex-with stairs" (dimensional characteristics category), "space recovery-saving space" (efficient/ inefficient area utilization category), "house for single people, designed only for men/women" (category of different groups of users) were made by participants. It can be expressed that loft spaces are described as places with space recovery and customized locations according to user type and usage characteristics.

- Inflexible space category, however, was generally described as "too many furniture, complex" (category of the impression space stirs) and "medium-size" (dimensional characteristics category). Taking these into consideration, it can be pointed out that participants generally perceive these spaces narrower in terms of dimension and find them more chaotic and complicated in terms of the impression they stir.

\section{Results and Discussion}

Within this work, people's perception of flexibilityrelated house interior photographs is examined. The most significant findings obtained within the study can be summarized as follows; all participants, while reviewing flexibility-related photographs, pay attention to dimensional characteristics of space in the first place, the good or bad impression it stirs on individual in the second

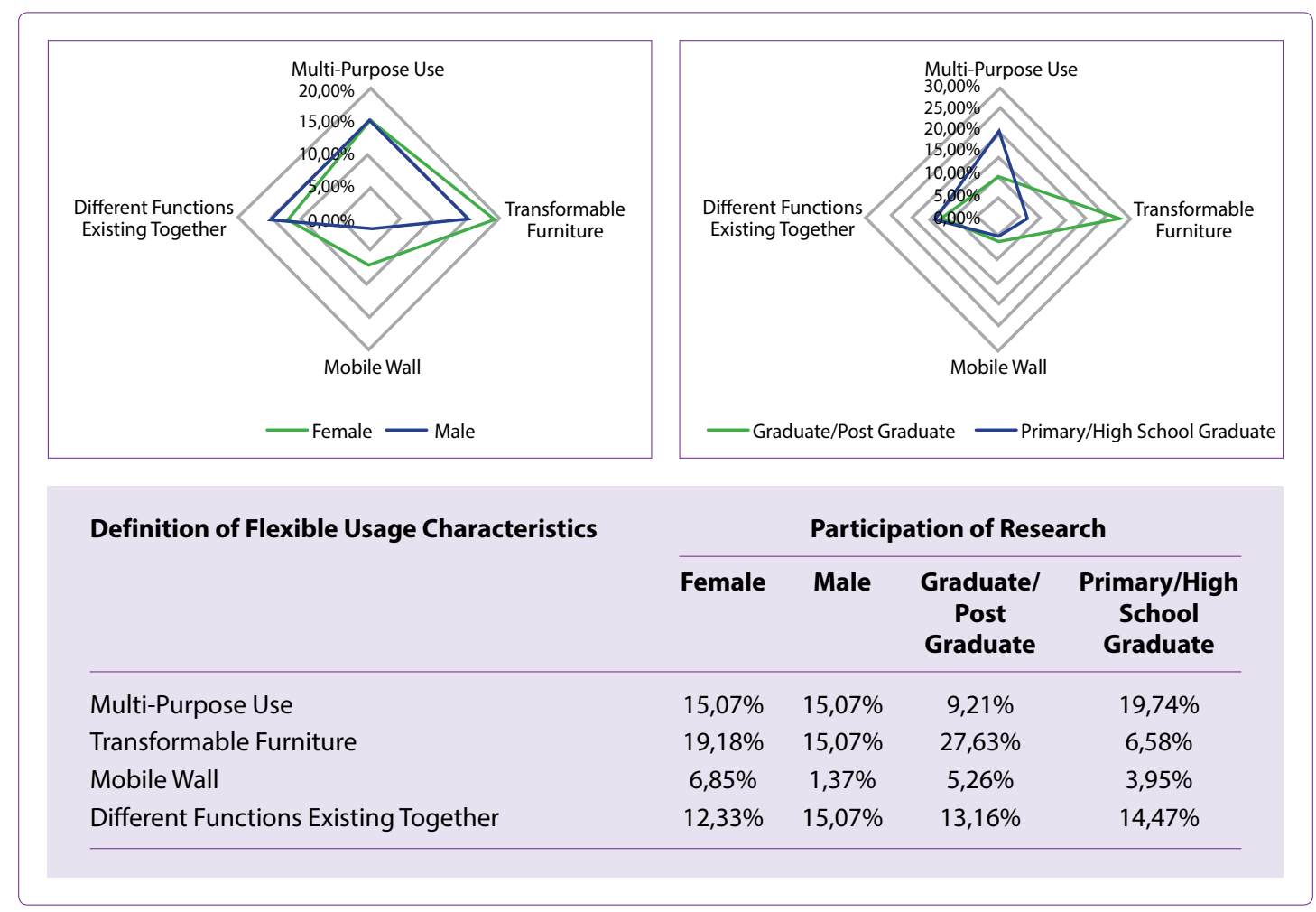

Figure 7. Perspective and description percentages of flexible usage characteristics according to gender and educational status differences. 
place and flexibility feature of space in the third place. At this point it is seen that dimensional characteristics of space and spatial impression are related to flexibility in a way, as participants point out. Participants find spaces, which are designed in bigger dimensions (width-lengthvolume-etc.) and leave a positive impression on them, more suitable for flexible space usage and think that these spaces increase flexible usage characteristics. At this point, it can be expressed that, dimensional characteristics of house (as well as other features) have a great role on the impact created on the individual. Especially while wide spaces which have open space in flexible house are described with a "pleasant" effect by participants, flexible spaces generated with transformable furnishing elements usually appear to have a more "suffocating" effect on participants. Based on these descriptions, it is conceived that, participants usually don't appreciate and prefer flexible usage provided through transformable furnishing elements.

Participants describe spaces that display flexible usage characteristics, in other words flexibility in house, as "spaces that enable multi-purpose use and containing transformable, functional, practical and foldaway furniture".

Moreover, it can be said that participants in the study emphasize different points according to their gender and educational status differences, while describing photographs related to flexibility. It also can be pointed out that according to gender difference, female participants pay more attention to the impression that space stirs and its flexible usage characteristics, while male participants pay more attention to its style and usage characteristics. The reason of this case is interpreted as female participants spend more time inside the house compared to male participants and their demand to use the space more effectively is higher than the males. As for male participants on the other hand, it can be expressed that as they spend less time inside the house and contribute less to indoor activities, they comment on issues like style and decoration of the house more compared to female participants. At this point, findings, which state that women have more introvert and men have more extravert natures in the house, are obtained supporting Ergöz Karahan and Özüekren's (2010) studies.

If we look at participants' education differences, it can be noted that as education levels increase, aesthetics of space gain importance and on the contrary as education levels decrease functionality of space is highlighted. The reason for this can be reviewed as the demand that is formed as a natural consequence of an increase in education levels and this leading to different aesthetic pursuits. In this study, it would be also right to state that aesthetic concern increases in accordance with education levels, as there are findings supporting Stuart-Fox's (2015) study which points out that with an increase in education levels, users also pay attention to symbolic-aesthetic-experimental aspects of space as well as functional characteristics of it.

If we need to divide the category of flexible usage characteristics, which mainly involves of photographs of transformable furniture and mobile wall, according to gender and education level differences, female participants describe transformable furniture in the first place in the category of flexible usage characteristics. The reason for this can be explained as the notion of furniture, which enables different functions, creates flexible usage, as female participants use house much more. Likewise, users, who relate flexibility with transformable furniture as education levels increase, review flexibility as multipurpose usage as education levels decrease. The reason for this is reviewed as increase in awareness about equipment technologies in the space and transformable furniture as a natural result of increase in education levels.

In the light of all the data gathered, it can be said that in house design, open plans, which are designed in a way that enables flexible usage with broad and spacious, not tiring, multi-purpose/multi-functional free spaces containing optimum amount of object, will bring an advantage in terms of the change and transformation the space experiences in time and make great contribution to house manufacturing in terms of economy and sustainability. In addition to that, it is considered that flexibility is/will not be preferred in circumstances where it is tried to be achieved with mobile wall and transformable furniture and associated to narrow and small characteristics of space.

Data, obtained within the study demonstrate that flexibility should be reviewed with dimensional characteristics of space and the impression it stirs, a space is preferred by participants when it is flexible, board and spacious but not preferred when it is not perceived as broad or spacious even though it is flexible.

In conclusion, the data and the reviews, obtained and presented within this user-oriented study, are thought to provide significant tips for developing economic and sustainable housing manufacture in our country and contribute to future studies in this field.

\section{References}

Al-Dakheel, R.M. (2007). The Role of Flexibility in Sustainable Prototype Unit Design: Riyadh Commercial Housing Developments, RCHD, Case Study. vol.35, no.2, p.545-567.

Aras, L. (2016). Yerin Ruhunun İzleri: Mimarlığın Masumiyet Çağına Dönüşü. Sosyoloji Divanı, 7, Ocak-Haziran.

Bektaş, C. (1996). Türk Evi. Yapı Kredi Yayınları, İstanbul.

Boumeester, H. (2011). Traditional Housing Research Demand. In Jansen, S.J.T., Coolen, H. \& Goetgeluk, R., (eds), The Mea- 
surement and Analysis of Housing Preference and Choice. Dordrecht: Springer.

Deniz, Ö.Ş. (1999). Çok Katlı Konut Tasarımında Kullanıcıların Esneklik Taleplerini Karşılayacak Yapı Elemanlarının Seçimine Yönelik Bir Karar Verme Yaklaşımı. Doktora Tezi, iTü Mimarlık Fakültesi, İstanbul.

Devlin, K. (1990). An Examination of Architectural Interpretation: Architects Versus Non-Architects. The Journal of Architectural and Planning Research, 7:3, p.235-244.

Erdoğan, E. (2010). Mimarlık Eğitiminin Görsel İmajların Yorumu Üzerine Etkisi. Selçuk Üniversitesi, Fen Bilimleri Enstitüsü, Doktora Tezi.

Ergöz Karahan, E., and Özüekren, A.Ş. (2010). Gender in Housing Career. Urban Dynamics \& Housing Change - Crossing into the 2nd Decade of the 3rd Millennium, 22nd International Housing Research Conference, 4-7 July, İstanbul.

Gilani, G. (2012). Evaluating Flexibility Notions in Mass Housing of North Cyprus through Learning from Her Rural Vernacular Architecture. Master of Science in Architecture, Eastern Mediterranean University, Gazimağusa, North Cyprus.

Groat, L. (1982). Meaning Post-Modern Architecture: An Examination Using the Multiple Sorting Task. Journal of Environmental Psychology, 2, p.3-22.

Groat, L., and Wang, D. (2013). Architectural Research Methods. Second Educations, Canada.

Gülaydın, D. (2004). Konutta Memnuniyet ve Tasarım İlişkisi Açısından Çekirdek Konutlarda Esneklik Araştırması. İstanbul Teknik Üniversitesi, Yüksek lisans tezi.

Habraken, N.J. (1972). Supports: An Alternative to Mass Housing. The Architectural Press, London.

Habraken, N.J. (2002). Uses of Levels. Open House International, vol.27, no.2, June, p.9-20.

Hershberger, R.G. (1988). A Study of Meaning and Architecture. Environmental Aesthetics, Theory, Research And Applications, ed.: Jack L. Nasar, p.175-194.

Hertzberger, H. (1991). Lessons for Students in Architecture. Netherlands.

Karni, E. (1995). Enhancing User Flexibility in Adaptable Dwelling Units in High-rise Public Housing. Vol.20, No: 2.

Kızmaz, K.C., and Çimşit Koş, F. (2015). Esneklik Kavramında Kullanıcı Kathlımının Önemi ve Güncel Yaklaşımlar. Beykent Üniversitesi Fen ve Mühendislik Dergisi, Sayı 8 (2), 111-142.

Küçükerman, Ö., and Güner, Ş. (1994). Anadolu Mirasında Türk Evleri. Kültür Bakanlığı Yayınları, Sanat Tarihi Dizisi.

Lans, W., and Hofland, C.M. (2005). Flexibility, How to Accommodate Unknown Future Housing Requirements. XXXIII IAHS World Congress on Housing Transforming Housing Environments through Design.

Monterrey Houses: https://www.archdaily.com/52202/monterrey-housing-elemental/50089c3028ba0d50da001309-monterrey-housing-elemental-photo?next_project=no (Data of Access: 7.11.2020)

Priemus, H. (1993). Flexible Housing: Fundamentals and Background. Open House International, vol.18, no:4.

Sanoff, H. (1973). Youth's Perception \& Categorizations of Residental Cues. Environmental Design Research, Volume I, Selected Papers, p. 84-97.

Sanoff, H. (1991). Visual Research Methods in Design. New York.
Schneider, T., and Till, J. (2007). Flexible Housing. New York, Elsevier, Oxford.

Scott, M.J., and Canter, D.V. (1997). Picture or Place? A Multiple Sorting Study of Landscape. Journal of Environmental Psychology, 17, 263-281.

Stuart-Fox, M. (2015). Higher Educated Residential Preference and The Marketing of Private Housing in the Amsterdam Metropolitan Area and Hong Kong. Research Master Urban Studies Thesis, University of Amsterdam.

Torun, O. (2018). Gelenek ve Çağdaşlık Kesitinde Türk ve Japon Evi. Maltepe Üniversitesi, Yüksek lisans Tezi.

TUIK, 2020, Address Based Population Registration System, https://data.tuik.gov.tr/Bulten/Index?p=AdreseDayal\%C4\%B1-N\%C3\%BCfus-Kay\%C4\%B1t-SistemiSonu\%C3\%A7lar\%C4\%B1-2019-33705\&dil=1 (Date of Access: 3.12.2020)

TUIK, 2020, Housing Sales Statistics, https://data.tuik. gov.tr/Bulten/Index? $\mathrm{p}=$ Konut-Satis-Istatistikleri-Agustos-2020-33883 (Date of Access: 3.12.2020)

TUIK, 2020, Building Permit Statistics, https://data.tuik. gov.tr/Bulten/Index? $\mathrm{p}=$ Yapi-Izin-Istatistikleri-Ocak-Eylul,-2020-33782 (Date of Access: 3.12.2020)

Quinta MonroyHouses: https://www.archdaily.com/10775/quinta-monroy-elemental/50102df128ba0d4222000ff7-quinta-monroy-elemental-image?next_project=no (Data of Access: 28.04 .2020$)$

Wilson, M.A. (1989). The Development of Architectural Concepts: A Comparative Study of Two Schools of Architecture. Doctor of Philosophy Thesis, University of Surrey.

Yürekli, F. (1983). Mimari Tasarımda Belirsizlik: Esneklik-Uyabilirlik İhtiyacının Kaynakları ve Çözümü Üzerine Bir Araştırma. iтÜ Mimarlık Fakültesi, İstanbul.

\section{Table 1- References for the Photographs Used in the Study (Internet Resources)}

Photograph 1: https://www.archdaily.com/891738/loft-sao-paulo-treszerosete/5ac1df29f197ccce9f000565-loft-sao-paulo-treszerosete-photo [Date of Access 2.04.2019]

Photograph 2: https://www.porterdavis.com.au/blog/ posts/2016/10/open-plan-living [Date of Access 14.04.2019]

Photograph 3: https://interiorzine.com/2018/05/17/22-hide-abed-ideas/ [Date of Access 4.07.2019]

Photograph 4: https://www.homedit.com/columns-inside-outside-house/living-room-column-arch/ [Date of Access 4.04.2019]

Photograph 5: https://interiorzine.com/2018/05/17/22-hide-abed-ideas/ [Date of Access 4.07.2019]

Photograph 6: https://www.homedit.com/modern-loft-remodel/brazil-industrial-loft-by-diego-revollo-arquitetura-industrial/ [Date of Access 7.07.2019]

Photograph 7: http://www.mimarlar.com/8BF4751E275541FA8331043A7C36B7E5/b3_evi/ptype [Date of Access 23.04.2019]

Photograph 8: https://www.huffpost.com/entry/movable-wallsa-solution-for-small homes_n_562a51fde4b0443bb563ad3b [Date of Access 31.03.2019]

Photograph 9: http://ceburattan.com/3134-four-season-porchdesigns/ [Date of Access 17.06.2020] 
Photograph 10: https://interiorzine.com/2018/05/17/22-hidea-bed-ideas/ [Date of Access 4.07.2019]

Photograph 11: https://livingroomideas.eu/10-loft-style-livingroom-design-ideas/ [Date of Access 5.07.2019]

Photograph 12: https://www.washingtonian.com/2019/05/30/ the-five-best-looking-open-houses-this-weekend-6-1-6-2/ [Date of Access 5.07.2019]

Photograph 13: https://www.6sqft.com/peter-kostelov-transforms-a-dark-uptown-apartment-into-a-multifunctionalhome-with-sliding-furniture/ [Date of Access 19.07.2019]

Photograph 14: http://4betterhome.com/modern-classic-house-interior-with-eclectic-touch/ [Date of Access 22.04.2019]

Photograph 15: https://www.housebeautiful.com/room-decorating/a4443/ikea-moveable-walls/ [Date of Access 31.03.2019]

Photograph 16: https://livingroomideas.eu/10-loft-style-livingroom-design-ideas/ [Date of Access 5.07.2019]
Photograph 17: https://homedroidtheme.blogspot. com/2020/01/open-space-interior-design-ideas.html [Date of Access 4.12.2020]

Photograph 18: https://www.dwell.com/article/everything-in-place-living-big-enorme-studio92f84c7d/6459895036419846144 [Date of Access 6.07.2019]

https://www.dwell.com/article/everything-in-place-living-bigenorme-studio-92f84c7d/6459895038928039936 [Date of Access 6.07.2019]

Photograph 19: http://images.traditionalhome.mdpcdn.com/ sites/traditionalhome.com/files/slide/101664116_p.jpg [Date of Access 18.06.2020]

Photograph 20: https://www.dwell.com/article/everything-in-place-living - big-enorme-studio92f84c7d/6459894990953291776 [Date of Access 6.07.2019] https://www.dwell.com/article/everything-in-place-livingbig-enorme-studio-92f84c7d/6459894985627451392 [Date of Access 6.07.2019] 